\title{
The Linkage of Employee Satisfaction and Loyalty in Hotel Industry in Klang Valley, Malaysia
}

\author{
Rahman Bin Abdullah \\ Faculty of Hotel and Tourism Management, Universiti Teknologi MARA, Dungun, 23000, Terengganu, Malaysia \\ Tel: 60-9-8401-913/60-19-741-6820 E-mail: rahma255@tganu.uitm.edu.my \\ Noraida Bte Abdul Karim
}

Faculty of Hotel and Tourism Management, Universiti Teknologi MARA, Dungun, 23000, Terengganu, Malaysia

Tel: 60-9-8403-772/60-12-2773-736_E-mail: norai297@tganu.uitm.edu.my

Mohd Onn Rashidi Bin Abdul Patah

Faculty of Hotel and Tourism Management, Universiti Teknologi MARA, Dungun, 23000, Terengganu, Malaysia

Tel: 60-9- 8401-913/ 60-13 -9342-148Ｅ-mail: onnrashdi@gmail.com

Harnizam Zahari

Faculty of Hotel and Tourism Management, Universiti Teknologi MARA, Dungun, 23000, Terengganu, Malaysia

Tel: 60-9- 8481-700/60-12 -6896-581 E-mail: harnizamz@tganu.uitm.edu.my

Gopala Krishnan Sekharan Nair

Academy of Language Studies, Universiti Teknologi MARA, Dungun, 23000, Terengganu, Malaysia

Tel: 60-9- 8403-825/60-12-9002-6026 E-mail: gopal792@tganu.uitm.edu.my

Kamaruzaman Jusoff (Corresponding author)

TropAIR, Faculty of Forestry, Universiti Putra Malaysia, UPM Serdang 43400, Selangor. Malaysia

Tel: 60-3-8946-7176 E-mail: kjusoff@yahoo.com

\begin{abstract}
Many organizations in the hotel industry face difficulties in retaining employees since they are unable to identify the factors that contribute to both employee satisfaction and loyalty. This study, covers 13 satisfaction variables and 3 loyalty variables. Employment tenure, employee future plan with the company, and recommending employment in the company would be taken as the 3 loyalty indicators in this study. This study sought to identify factors which could lead to increased tenure, in addition, any linkage between employee satisfaction and employee loyalty was investigated. In order to do that, a business model, called the Service Profit Chain was used and applied in hotels in the Klang Valley area in Malaysia. A portion of the model that measures employee satisfaction and employee loyalty was adopted for this study. The findings indicate the existence of a correlation between employee satisfaction and employee loyalty. Four of the thirteen satisfaction variables, namely, relationship with supervisor, recognition and rewards, working conditions, teamwork and cooperation showed the strongest correlation with the three loyalty variables afore mentioned. It is hoped that the findings could be used by managers in the service industries in developing effective employee training programmes by placing emphasis on the four satisfaction variables which correlated strongly with the three loyalty variables. However, since the sample of this study comprises only the front line employees, it is hoped that a future extended study would be carried out which would include the back of the house staff as well. If the findings are similar, then the theories of employee satisfaction and loyalty would apply equally to the entire hotel staff and this would greatly assist hotels in organizing uniform, effective and cost saving training programmes for all the staff to increase the level of employee satisfaction and loyalty for the mutual benefit of the employee and the organization.
\end{abstract}

Keywords: Service profit chain, Employee satisfaction, Employee loyalty, Linkage

\section{Introduction}

Interest in the potential and quality of the service industry has increased significantly both in the industry itself and in the academic field over the past 20 years. As many countries shifted from a manufacturing base towards a service based 
economy, both the industry as well as the academia started to pay close scrutiny to it (Fitzsimmons \& Fitzsimmons, 2006). As a result, studies of service management have grown to become an important element in the academic field. In this study the service profit chain model by Heskett et. al. (1997) which is one of the significant conceptual frameworks in service management will be adopted. However, only a portion of the service profit chain that links employee satisfaction to employee loyalty in the context of the hotel industry will be discussed in the literature.

In Malaysia, the hotel industry has been recognized as a potential prospect in the growth of the service industry. However, the growth is impeded by the high turnover rates of employees in the hotel industry. Many organizations in the hotel industry face difficulties in retaining employees since they are unable to identify the factors which contribute to employee satisfaction and the resultant loyalty. This study would endeavor to identify the factors which would actually make employees stay in their current working place. Additionally, the linkage between employee satisfaction and employee loyalty will be investigated.

The management of many organizations develops their training programmes, benefit packages, performance appraisal and work system based on their company policy. Usually these policies are aimed at developing loyal employees because this leads to a more lengthy tenure. The longer an employee works for a company the more valuable they become, especially in the service industry. On the other hand, there are retail companies which would only be focusing on employee satisfaction instead of prioritizing on employee loyalty. It is hoped that the findings of this study would assist organizations in coming up with staff training programmes, which would help create employee satisfaction and loyalty. In order to do that, a business model called the Service Profit Chain by Heskett et. al. (1997) was used and applied in hotels in the Klang Valley area in Malaysia. A fraction of the model that identifies employee satisfaction and employee loyalty was used in the questionnaire. The questionnaire is designed to elicit information which would be used to investigate the linkage between satisfaction and loyalty. The service profit chain is a concept introduced by Heskett et. al. (1997). The model was created to answer why certain service organizations perform better than the others (Heskett et. al., 1997).

The service profit chain model postulates that there are direct and strong networks of relationships between variables such as profit, growth, customer loyalty, customer satisfaction, the value of goods, services delivered to customers, employee capability, satisfaction, loyalty and productivity. Heskett et al. (1997) established the linkage by collecting empirical evidence from some 20 large service organizations. The findings lend support to the linkages stipulated in the service profit chain model. The model espouses the following chain of relationships, namely, that profit and growth are linked to customer loyalty, customer loyalty is linked to customer satisfaction, in turn, customer satisfaction is linked to service value while service value is linked to employee productivity, whereas employee productivity is linked to employee loyalty, employee loyalty is in turn linked to employee satisfaction, and employee satisfaction is linked to internal quality of work life (Heskett et al, 1997). The internal quality of work life, according to Heskett et al. (1997) simply denotes the feelings that employees have towards their jobs, colleagues, and the organization.

According to Heskett et al (1997), the strongest relationship as indicated by the data collected in the early tests of the service profit chain model, were those between: (1) profit and customer loyalty, (2) employee loyalty and customer loyalty, and (3) employee satisfaction and customer satisfaction. They suggested that in service settings, the relationships were self- reinforcing. That is, satisfied customers contributed to employee satisfaction, and vice versa. The chain starts with the productivity and quality of the output from the employees which has a linkage with employee loyalty; employee loyalty has a linkage with employee satisfaction and employee satisfaction is linked to employee capability. The customer value equation suggests that the value of goods and services delivered to customers is equivalent to the sum total of all the activities which contributed to the service value. The value is also dependant on the quality of the processes used to deliver the results, this is in relation to the price of a service to the customer and other costs incurred by the customer in acquiring the service. Furthermore, Heskett et al (1997) has found that value defined in this way is directly related to customer satisfaction. Subsequently, customer satisfaction has been found to have a linkage with customer loyalty, which eventually, theoretically leads to revenue growth and profitability which is the main objective of many organizations.

\section{Materials \& method}

This is a descriptive study using statistical data to generate results. This research uses a survey method which focuses on contemporary events and does not require control over behavior of events. A close ended survey questionnaire was used in order to assess employee satisfaction and employee loyalty in hotels in Malaysia, which participated in this study. Most of the items in the questionnaire were adopted from Loveman (1998). He had used the questionnaire to measure employee satisfaction in retail banking.

A few items in the questionnaire were taken from the instrument used by Fosam et al (1998) which measures employee satisfaction and employee loyalty. The remaining items in the questionnaire was adapted from existing questionnaires that were taken from various literature review with appropriate adjustments

The questionnaire includes 19 items all together, with each item consisting of few sub questions. The questionnaire was divided into 3 sections; namely demographic data section, employee satisfaction section and employee loyalty section.. 
All the items in the questionnaire have an established validity and reliability based on Loveman (1998) and Fosam et al (1998) questionnaire items.

The questionnaires were distributed to the frontline employees of the participating hotels in the Klang Valley in Malaysia. A total of 300 questionnaires were distributed and a total of 258 questionnaires were retrieved for analysis.

Descriptive analysis involving frequencies were carried out to establish the percentage of employee satisfaction and loyalty. A scatter plot was generated in order to see the connection between employee satisfaction and employee loyalty. After that, correlation tests were conducted to see the relationship strength between employee satisfaction variables and the employee loyalty components as characterized earlier.

\section{Results and discussion}

All the data pertaining to employee satisfaction was analyzed using frequencies in order to identify factors that led to employee satisfaction. Subsequently, the employee satisfaction data was cross tabulated and correlated with the employee loyalty data. This was done in order to identify factors in the employee satisfaction section correlated positively to the three forms that denotes employee loyalty, namely, employment tenure, the making of career advancement plans within the company and recommending the employment to others. The linkage between employee satisfaction and employee loyalty was ascertained through these tests.

According to Table 1, most employees were basically satisfied. Their satisfaction stems from several factors. However, the study also found that employees place certain elements of their satisfaction as more important than the others. This seems to be evident when in general the employees say they were satisfied, but when being asked of each item in the questionnaire, some variables produced a better satisfaction score than the others (Table 2).

Before assessing whether the variables have any significant relationship. A Pearson Chi Square test was conducted to see the degree of confidence. The stated confidence level is the percentage equivalent to the decimal value of $1-\alpha$, and vice versa. A $95 \%$ confidence interval is to be found at, $\alpha=0.05$, since $1-0.05=0.95$, or $95 \%$. When $\alpha=0.01$, then $1-\alpha=$ $1-0.01=0.99$, and the confidence interval is $99 \%$. For the purpose of this study, a confidence level of $95 \%$ is used.

In terms of age, most of the respondents are aged between 21 and 34. This is an indication that the majority of the respondents are also a representation of Generation X (born between 1996 and 1982). The finding was that the majority of the respondents are loyal and the literature shows that Generation $X$ have the tendency to be more loyal towards their employers than generation Y (born between 1978 and 1994). However, their loyalty is only as long as the business they are working with is still good. In other words, Generation $\mathrm{X}$ value loyalty at the workplace as long as the mutual need between employee and employer is fulfilled.

The respondents also seem to regard highly matters concerning career advancement and the opportunities to learn and grow that is offered by their organization. This finding agrees with the results of Walker Information's 2005 study which found that satisfied employees will become loyal when they perceive their organization as offering the opportunities to learn, grow and at the same time providing a clear established career path that they can pursue in the organization. These findings coincided with the employee commitment studies carried out by Carlson (2005). Carlson concluded that in order for the employees to be committed, which is a broad definition of loyalty, they look forward to the opportunities of continuous learning in order to improve their skills and knowledge.

Performance appraisal plays a role in the relationship between employee satisfaction and employee loyalty in this study. According to Jawahar (2006), performance appraisal is an important element of satisfaction because it is positively related to job satisfaction, organizational commitment and negatively related to turnover intentions. Job satisfaction and organizational commitment fall into a broader definition of loyalty. When mentioning turnover, it implies that the employee would not be loyal if the performance appraisal system is not fair and it does not accurately reflect true employee performance. Jawahar (2006) found that employee satisfaction has a linkage with employee loyalty, however in this study, performance appraisal, which is one of the thirteen variables denoting employee satisfaction did not correlate significantly with any of the three dimension of employee loyalty.

On the other hand, employee's role, which is also a variable denoting employee satisfaction, was found to correlate with employee loyalty in this study. The study of employee's role found that empowerment could lead employees to a higher level of satisfaction and a better quality of work life. Studies on employee empowerment/involvement programs were carried out by The Center for Effective Organizations at the University of Southern California and reported by Lawler et. al., 1992, 1995). They surveyed Fortune 1000 companies in 1987, 1990, and 1993 to determine the degree to which firms are adopting practices that redistribute power, information, knowledge, rewards, and the effects. Their 1990 and 1993 data was obtained from a sample which consisted of a mixture of manufacturing and service firms. The findings indicated that empowerment may have a positive impact on a number of performance indicators. However, in the service context, before the management decides to give a certain level of empowerment to their employees, especially to those whom are in constant contact with customers, the management must ensure that the empowerment is in no way abused. Management discretion in granting empowerment is essential in ensuring that such empowerment brings mutual benefit to both 
employee and employer. This is in line with the Customer Oriented Service Employee (COSE) constructed by Kelley (1992).

Hennig (2004) defines COSE as the extent to which the employee's behavior in personal interactions with customers meets those of customer needs. It is important to note that the conceptualization of COSE as suggested here implies that all four dimensions (technical skills, social skills, motivation and decision making power) are indispensable to a certain extent to enable employees to behave in a customer oriented way. In order for the employees to perform all the other three dimensions, employees should be allowed a certain degree of decision making power, or they are empowered to decide what is best for the customer. However, this should only be carried out when the employees are able to fulfill all the other three dimensions.

Recognition and rewards is also one of the elements that have been found to link with employee loyalty in this study. Schneider (1994) alleges that customers report superior service when employees indicate that they work in a positive climate for service. Such climate refers to employee perceptions of the practices, procedures and behaviors that get rewarded, supported and expected with regard to customer service and customers service quality (Schneider et. al., 1998). The notion of employee as a customer has been previously developed. For example, Berry (1981) states that whether managing customers or employees "the central purpose remains the same: the attraction of patronage through the satisfaction of needs and wants". In both cases individuals and organizations are involved in the exchange. The nature of what is exchanged may vary, but the importance of satisfying needs and wants remains constant, meaning that the management of employees is often similar to the management of customers. Similarly, employee needs and wants are satisfied when they perceive that rewards from the organization (e.g. pay, promotion, recognition, personal growth, meaningful work) meet or exceed their expectations (Hackman and Oldham, 1980; Locke, 1976).

This study also established the link between working conditions (employee satisfaction variable) and the three dimensions of employee loyalty. In the service profit chain model, the antecedents of employee satisfaction are variables related to "internal service quality" and include workplace and job design. According to Schneider (1994), customers report superior services when employees indicate that they work in a positive climate for service. Subsequently, Walker Information's 2005 found that employees are more loyal when they feel that their job is secure, which is one of the items included under working condition section in this study. Working condition seems to have a significant relationship with employee loyalty in this study (Table 5).

In addition, studies of employee's satisfaction had identified areas that seem to be important for the satisfaction of the employees. The areas include a well managed, supportive and prosperous work environment, ongoing professional development, career growth potential, challenging and exciting work, teamwork, acknowledgement of work well done, work life balance and the work culture (Tarasco \& Damato, 2006). Their study seems to agree in most aspects with the findings of this study. However, the strongest correlation between employee satisfaction and employee loyalty in this study comes from the following satisfaction variables, namely, recognition and rewards, teamwork and cooperation, working conditions and relationship with supervisor. The score for relationship with supervisor, strongly correlates with all three dimensions of employee loyalty. Sturgeon (2006) states that worker's relationship with their immediate supervisor is very important to employees since both are working in the same organization and share the same workplace. Anonymous (2005) reported that, when employees leave their job because they are not satisfied, they don't leave their job and company, but they are divorcing their manager or supervisor. In addition, he added, fostering satisfaction among subordinates is often largely affected by the capabilities of the manager or supervisor. On the other hand, training was also found to be a major contributor to employee satisfaction. However, in this study, it does not have a significant relationship with employee loyalty. Sturgeon (2006) agrees that training is one of the main drivers of employee satisfaction. Tarasco \& Damato (2006) identified training in the form of ongoing professional development is an important contributory factor to employee satisfaction. In addition to that, Walker Information's 2005 also found that training and development to be one of the biggest factors that lead to employee loyalty. According to the report, employees want the opportunity to grow, and they want career path and opportunities that allow them to advance within the company. This study found that the benefits package, correlated with employee loyalty measures. Benefits package take into account factors such as, the amount of vacation, sick leave policy, amount of health care paid for by the organization, and dental benefits.

These results appear to agree with the model of the service profit chain developed by Heskett'et al (1997). The model shows that there is a relationship between employee satisfaction and employee loyalty. In addition to that, the findings of this study appears to agree with Heskett et al (1997) that workplace conditions, job design/decision making latitude, rewards \& recognition, information \& communication, and adequate "tools" to serve customers and are factors that lead to employee satisfaction. The findings of employee satisfaction and employee loyalty in this study does corroborate the linkage proposed by Heskett et al (1997), in which, it is claimed that there is a strong relationship between employee satisfaction and employee loyalty. The findings of this study show that Heskett's theories are also applicable to the hotel industry, this corroboration is important since the findings of Heskett et al were from other fields of service. 
In light of these findings, hotel organizations might want to construct a more comprehensive employee career development program that not only helps in improving employee satisfaction, but also uplifts their loyalty level. Factors such as recognition and rewards, teamwork and cooperation, working conditions, and relationship with supervisors are variables which seem to correlate satisfactorily to employee satisfaction and loyalty. These factors should be strongly emphasized in creating employee career development programs. However, a much more comprehensive study with a sample which comprises both the frontline and the non frontline hotel employees should be carried out in the future to find out whether the findings are also relevant and applicable to the back stage boys. If it should apply equally to the back stage staff then the findings can be used to create relevant staff development programme for the whole of the hotel staff and not just for the frontline people.

\section{Conclusion}

These findings underscore the important postulation that there is linkage between employee satisfaction and employee loyalty. In other words an increase of employee satisfaction could actually result in increased in employee participation and has the potential of making both the employee and employer equally loyal to the company. Basically employee satisfaction is dependant on benefits package, training and development, relationship with supervisor, working conditions, teamwork and cooperation, recognition and rewards, empowerment and communication. Whereas, employee loyalty is a result of the satisfaction that stems from satisfaction variables such as, recognition and rewards, working conditions, teamwork and cooperation, and relationship with supervisor.

These four satisfaction variables correlates with all the three aspect of loyalty in this study, namely, employment tenure, planning career with company and recommending employment (Table 3,4,5, and 6). The findings of this study could be used by managers in organizations in developing their staff training programme in order to create satisfied and loyal workers. Companies should be mindful of satisfaction variables such as: recognition and rewards, teamwork and cooperation, working conditions, and relationship with supervisor. The training programmes should make the employees confident that the company is sincere about the satisfaction variables such as mentioned in the preceding sentence. However, a future extended study that evaluates a wider scope of employee satisfaction and loyalty dimensions in the hotel industry should be conducted using a sample which includes the back of the house employees as well in order to establish the various strength between the variables in this study amongst the different samples. This would enable them to come up with a comprehensive training programme which is uniform to all hotel staff irrespective of whether they are in the frontline or the back room.

\section{References}

Berry, L.L. (1981). The employee as customer. Journal of Retail Banking, March. pp. 33-40.

Fitzsimmons, J., and Fitzsimmons M.J. (2006). Service Management: Operations, Strategy, Information Technology. Fifth Edition. McGraw Hill. New York.

Fosam, E.B., Grimsley, M.F.J., and Wisher, S.J. (1998). Exploring models for employee satisfaction; with particular reference to a police force. Total Quality Management, Vol. 9, No. 2 and 3, pp. 235-47.

Hackman, J.R. and Oldham, G.R. (1980). Work Redesign, Addison-Wesley, Reading, MA.

Hennig T. T. (2004). Customer orientation of service employees: Its impact on customer satisfaction, commitment and retention. International Journal of Service Industry Management, Vol. 15, No. 5, pp. 460-478.

Heskett, J.L, Sasser Jr, W.E. and Schlesinger, L.A. (1997). The service profit chain: How Leading Companies Link Profit and Growth to Loyalty, Satisfaction and Value, free press, New York, NY.

http://www.marketresearchworld.net/index.php?option=com_content\&task=view\&id=1326\&Itemid=77Are Your Employees Ambassadors or Saboteurs? Harris Interactive Unveils Employee Ambassadorship Research Solution: Links Employee Commitment to Customer Loyalty

Jawahar, I. M. (2006) Correlates of satisfaction with performance appraisal feedback. Journal of Labor research. Fairfax: Spring, Vol 27, Iss 2, p. 213.

Kelley, S.W. (1992). Developing customer orientation among service employees. Journal of Academy of Marketing Science, Vol. 20, No. 1. Pp. 27-36.

Lawler, E. E III, S.A. Mohrman and G.E. Ledford, Jr. (1995). Involvement and Total Quality Management. San Francisco, Jossey-Bass.

Lawler, E.E III, S.A. Mohrman and G.E. Ledford, Jr. (1992). Employee involvement and total quality management: Practices and results in Fortune 1000 companies. San Francisco: Jossey-bass publishers.

Locke, E.E. (1976). The nature and causes of job satisfaction. in Dunnette, M.D (Ed), Handbook of Industrial and Organizational Psychology, Rand McNally, Chicago, IL, pp. 1297-349 
Loveman, G.W. (1998). Employee satisfaction, customer loyalty, and financial performance. Journal of Service Research, Vol. 1, No. 1, pp. 18-31.

Schneider, B, White, S.S. and Paul, M.C. (1998). Linking service climate and customer perceptions of service quality; test of a causal model. Journal of Applied Psychology, Vol. 83, No. 2, pp. 150-63.

Schneider, B. (1994). HRM: A service perspective: Towards a customer focused HRM. International Journal of Service industry Management, Vol. 5, No. 1, pp. 64-76.

Sturgeon, J. (2006). Springing for Training. Government Executive. Washington. Vol. 38, Iss. 12, p. 20.

Tarasco J. A. \& Damato N. A. (2006). Build a better career path. Journal of Accountancy, New York. Vol. 201, Issue 5, p. 37.

Table 1. Employee satisfaction variables

\begin{tabular}{|c|c|c|c|c|c|}
\hline Variables & $\begin{array}{l}\text { Disagree } \\
\text { strongly }\end{array}$ & $\begin{array}{l}\text { Disagree } \\
\text { somewhat }\end{array}$ & Neutral & $\begin{array}{c}\text { Agree } \\
\text { Somewhat }\end{array}$ & Agree Strongly \\
\hline $\begin{array}{c}\text { Corporate } \\
\text { communications }\end{array}$ & & $13.3 \%$ & $19.6 \%$ & $54.4 \%$ & $12.7 \%$ \\
\hline $\begin{array}{l}\text { Employee Trust } \\
\text { company }\end{array}$ & & $10.8 \%$ & $15.8 \%$ & $57.0 \%$ & $16.5 \%$ \\
\hline $\begin{array}{l}\text { Communication } \\
\text { between dept }\end{array}$ & & $3.2 \%$ & $13.3 \%$ & $53.2 \%$ & $30.4 \%$ \\
\hline $\begin{array}{c}\text { Established Career } \\
\text { Path }\end{array}$ & & $5.1 \%$ & $15.2 \%$ & $57.0 \%$ & $22.8 \%$ \\
\hline $\begin{array}{l}\text { Opportunities to } \\
\text { Learn \& Grow }\end{array}$ & & $3.2 \%$ & $15.2 \%$ & $50.0 \%$ & $31.6 \%$ \\
\hline $\begin{array}{c}\text { Performance } \\
\text { Appraisal reflect } \\
\text { Performance }\end{array}$ & & $8.2 \%$ & 29.75 & $49.4 \%$ & $12.7 \%$ \\
\hline $\begin{array}{c}\text { Performance } \\
\text { Appraisal is Fair }\end{array}$ & $0.6 \%$ & $8.9 \%$ & $28.5 \%$ & $46.8 \%$ & $15.2 \%$ \\
\hline $\begin{array}{c}\text { Authority to make } \\
\text { decisions }\end{array}$ & $0.6 \%$ & $7.6 \%$ & $12.0 \%$ & $58.2 \%$ & $21.5 \%$ \\
\hline $\begin{array}{c}\text { Contribute to } \\
\text { Company Mission }\end{array}$ & & & $12.0 \%$ & $58.9 \%$ & $29.1 \%$ \\
\hline $\begin{array}{c}\text { Materials \& } \\
\text { Equipment to do } \\
\text { job well }\end{array}$ & & $7.0 \%$ & $10.1 \%$ & $60.1 \%$ & $22.8 \%$ \\
\hline $\begin{array}{l}\text { Good Work results } \\
\text { in more money }\end{array}$ & & $7.0 \%$ & $17.7 \%$ & $50.0 \%$ & $25.3 \%$ \\
\hline $\begin{array}{l}\text { Good Work results } \\
\text { in Promotion }\end{array}$ & & $13.3 \%$ & $35.4 \%$ & $37.3 \%$ & $13.9 \%$ \\
\hline $\begin{array}{l}\text { Employee valued at } \\
\text { company }\end{array}$ & $0.6 \%$ & $6.3 \%$ & $22.2 \%$ & $51.9 \%$ & $19.0 \%$ \\
\hline $\begin{array}{l}\text { Recognition for } \\
\text { good job }\end{array}$ & $0.6 \%$ & $6.3 \%$ & $17.7 \%$ & $55.7 \%$ & $19.6 \%$ \\
\hline $\begin{array}{l}\text { Salary equals the } \\
\text { responsibilities }\end{array}$ & & $9.5 \%$ & $22.8 \%$ & $49.4 \%$ & $18.4 \%$ \\
\hline $\begin{array}{l}\text { Feel part of a team } \\
\text { working toward a } \\
\text { shared goal }\end{array}$ & & $6.3 \%$ & $13.3 \%$ & $60.1 \%$ & $20.3 \%$ \\
\hline $\begin{array}{l}\text { Politics at company } \\
\text { kept to minimum }\end{array}$ & $4.4 \%$ & $27.8 \%$ & $29.7 \%$ & $29.7 \%$ & $8.2 \%$ \\
\hline
\end{tabular}




\begin{tabular}{|c|c|c|c|c|c|}
\hline $\begin{array}{l}\text { Feel committed to } \\
\text { work toward a } \\
\text { shared goal }\end{array}$ & $0.6 \%$ & $10.1 \%$ & $12.7 \%$ & $53.8 \%$ & $22.8 \%$ \\
\hline My job is secure & & $4.4 \%$ & $10.1 \%$ & $65.8 \%$ & $19.6 \%$ \\
\hline $\begin{array}{c}\text { Physical work } \\
\text { conditions are good }\end{array}$ & & $7.0 \%$ & $8.2 \%$ & $69.0 \%$ & $15.8 \%$ \\
\hline $\begin{array}{l}\text { Deadlines are } \\
\text { realistic }\end{array}$ & & $10.8 \%$ & $17.7 \%$ & $55.1 \%$ & $16.5 \%$ \\
\hline $\begin{array}{l}\text { Workload is } \\
\text { reasonable }\end{array}$ & $0.6 \%$ & $8.2 \%$ & $15.2 \%$ & $57.6 \%$ & $18.4 \%$ \\
\hline $\begin{array}{l}\text { Keep balance } \\
\text { between work and } \\
\text { personal }\end{array}$ & $0.6 \%$ & $5.7 \%$ & $5.7 \%$ & $56.3 \%$ & $31.0 \%$ \\
\hline $\begin{array}{l}\text { Supervisor treats } \\
\text { me fairly }\end{array}$ & $0.6 \%$ & $1.9 \%$ & $11.4 \%$ & $62.0 \%$ & $24.1 \%$ \\
\hline $\begin{array}{l}\text { Supervisor treats } \\
\text { me with respect }\end{array}$ & $0.6 \%$ & $0.6 \%$ & $11.4 \%$ & $65.2 \%$ & $22.2 \%$ \\
\hline $\begin{array}{l}\text { Supervisor handles } \\
\text { work related issues } \\
\text { satisfactorily }\end{array}$ & & $10.1 \%$ & $15.2 \%$ & $54.4 \%$ & $20.3 \%$ \\
\hline $\begin{array}{c}\text { Supervisor asks for } \\
\text { my input }\end{array}$ & $1.9 \%$ & $7.6 \%$ & $15.8 \%$ & $54.4 \%$ & $20.3 \%$ \\
\hline $\begin{array}{l}\text { Supervisor is an } \\
\text { effective manager }\end{array}$ & $3.2 \%$ & $6.3 \%$ & $17.1 \%$ & $50.6 \%$ & $22.8 \%$ \\
\hline $\begin{array}{l}\text { Company provide } \\
\text { as much initial } \\
\text { training as needed }\end{array}$ & & $5.1 \%$ & $24.1 \%$ & $48.1 \%$ & $22.8 \%$ \\
\hline $\begin{array}{l}\text { Company provides } \\
\text { as much ongoing } \\
\text { training as needed }\end{array}$ & $0.6 \%$ & $11.4 \%$ & $27.8 \%$ & $39.9 \%$ & $20.3 \%$ \\
\hline $\begin{array}{l}\text { Received the } \\
\text { training needed to } \\
\text { do my job }\end{array}$ & $0.6 \%$ & $8.2 \%$ & $20.3 \%$ & $48.1 \%$ & $22.8 \%$ \\
\hline $\begin{array}{l}\text { Training helps to } \\
\text { improve my work } \\
\text { performance }\end{array}$ & & $6.3 \%$ & $18.4 \%$ & $55.7 \%$ & $19.6 \%$ \\
\hline $\begin{array}{l}\text { Satisfied with } \\
\text { comp' benefit } \\
\text { package }\end{array}$ & & $2.5 \%$ & $14.6 \%$ & $69.0 \%$ & $13.9 \%$ \\
\hline $\begin{array}{c}\text { Satisfied with } \\
\text { amount of vacation }\end{array}$ & $1.3 \%$ & $1.9 \%$ & $15.2 \%$ & $68.4 \%$ & $13.3 \%$ \\
\hline $\begin{array}{l}\text { Satisfied with sick } \\
\text { leave policy }\end{array}$ & & $0.6 \%$ & $10.1 \%$ & $77.2 \%$ & $12.0 \%$ \\
\hline $\begin{array}{l}\text { Satisfied with } \\
\text { amount of health } \\
\text { care paid for }\end{array}$ & $0.6 \%$ & $4.4 \%$ & $8.2 \%$ & $74.1 \%$ & $12.7 \%$ \\
\hline $\begin{array}{l}\text { Satisfied with } \\
\text { dental benefits }\end{array}$ & $7.6 \%$ & $13.9 \%$ & $22.2 \%$ & $44.9 \%$ & $11.4 \%$ \\
\hline
\end{tabular}


Table 2. Percentage of employee satisfaction items in the questionnaire

\begin{tabular}{|c|c|}
\hline Items in the Questionnaire & Percentage of Employee Satisfaction \\
\hline I'm satisfied with the sick leave policy & $89.2 \%$ \\
\hline I feel I am contributing to the company's mission & $88 \%$ \\
\hline My supervisor treats me with respect & $87.4 \%$ \\
\hline $\begin{array}{c}\text { I can keep a reasonable balance between work and } \\
\text { personal life }\end{array}$ & $87.3 \%$ \\
\hline I'm satisfied with the amount of health care paid for & $86.8 \%$ \\
\hline My supervisor treats me fairly & $86.1 \%$ \\
\hline My job is secure & $85.4 \%$ \\
\hline My physical working conditions are good & $84.8 \%$ \\
\hline There is adequate communication between departments & $83.6 \%$ \\
\hline $\begin{array}{l}\text { I have enough materials \& equipment I need to do my } \\
\text { job well }\end{array}$ & $82.9 \%$ \\
\hline Overall, I am satisfied with the company' benefit package & $82.9 \%$ \\
\hline $\begin{array}{l}\text { I am satisfied with the amount of vacation I received for } \\
\text { my benefit package }\end{array}$ & $81.7 \%$ \\
\hline I have the opportunities to learn \& grow & $81.6 \%$ \\
\hline I feel part of a team working towards a shared goal & $80.4 \%$ \\
\hline I have a clearly established career path at this company & $79.8 \%$ \\
\hline $\begin{array}{l}\text { I am given enough authority to make decisions I need to } \\
\text { make }\end{array}$ & $79.7 \%$ \\
\hline I feel committed to work towards a shared goal & $76.6 \%$ \\
\hline My workload is reasonable & $76 \%$ \\
\hline If I do good work, I can count on making more money & $75.3 \%$ \\
\hline $\begin{array}{l}\text { This company gives enough recognition for work that's is } \\
\text { well done }\end{array}$ & $75.3 \%$ \\
\hline The training helps me to improve my work performance & $75.3 \%$ \\
\hline My supervisor handles work related issues satisfactorily & $74.7 \%$ \\
\hline My supervisor asks for my input to help make decisions & $74.7 \%$ \\
\hline I feel I can trust what company tells me & $73.5 \%$ \\
\hline My supervisor is an effective manager & $73.4 \%$ \\
\hline Deadlines at this company are realistic & $71.6 \%$ \\
\hline I feel I am valued at this company & $70.9 \%$ \\
\hline I received the training I need to do my job & $70.9 \%$ \\
\hline $\begin{array}{l}\text { The company provided as much initial training as I } \\
\text { needed }\end{array}$ & $70.9 \%$ \\
\hline My salary is fair for my responsibilities & $67.8 \%$ \\
\hline Corporate communications are frequent enough & $67.1 \%$ \\
\hline $\begin{array}{l}\text { My last performance appraisal accurately reflect my } \\
\text { performance }\end{array}$ & $62.1 \%$ \\
\hline The performance appraisal system is fair & $62 \%$ \\
\hline I am satisfied with the dental benefits & $56.3 \%$ \\
\hline If I do good work, I can count on being promoted & $51.2 \%$ \\
\hline "Politics" at this company are kept to a minimum & $37.9 \%$ \\
\hline
\end{tabular}


Table 3. Recognition and rewards (satisfaction) that led to employee loyalty

\section{Correlations}

\begin{tabular}{|ll|r|r|}
\hline & & M_LOYAL & M_RR \\
\hline M_LOYAL & Pearson Correlation & 1 & $.235^{*}$ \\
& Sig. (2-tailed) &. & .003 \\
& N & 158 & 158 \\
\hline M_RR & Pearson Correlation & $.235^{* *}$ & 1 \\
& Sig. (2-tailed) & .003 &. \\
& N & 158 & 158 \\
\hline
\end{tabular}

${ }^{* *}$. Correlation is significant at the 0.01 level (2-tailed).

Table 4. Teamwork and cooperation (satisfaction) that leads to employee loyalty

\section{Correlations}

\begin{tabular}{|ll|r|r|}
\hline & & M_LOYAL & M_TC \\
\hline M_LOYAL & Pearson Correlation & 1 & $.298^{* *}$ \\
& Sig. (2-tailed) &. & .000 \\
& N & 158 & 158 \\
\hline M_TC & Pearson Correlation & $.298^{* *}$ & 1 \\
& Sig. (2-tailed) & .000 &. \\
& N & 158 & 158 \\
\hline
\end{tabular}

**. Correlation is significant at the 0.01 level (2-tailed).

Table 5. Working conditions (satisfaction) that led to employee loyalty

\section{Correlations}

\begin{tabular}{|ll|r|r|}
\hline & & M_LOYAL & M_WC \\
\hline M_LOYAL & Pearson Correlation & 1 & $.328^{* *}$ \\
& Sig. (2-tailed) &. & .000 \\
& N & 158 & 158 \\
\hline M_WC & Pearson Correlation & $.328^{* *}$ & 1 \\
& Sig. (2-tailed) & .000 &. \\
& N & 158 & 158 \\
\hline
\end{tabular}

**. Correlation is significant at the 0.01 level (2-tailed).

Table 6. Relationship with supervisor (satisfaction) that led to employee loyalty

\section{Correlations}

\begin{tabular}{|ll|r|r|}
\hline & & M_LOYAL & M_SUPER \\
\hline M_LOYAL & Pearson Correlation & 1 & $.263^{* *}$ \\
& Sig. (2-tailed) &. & .001 \\
& $\mathrm{~N}$ & 158 & 158 \\
\hline M_SUPER & Pearson Correlation & $.263^{* *}$ & 1 \\
& Sig. (2-tailed) & .001 &. \\
& $\mathrm{~N}$ & 158 & 158 \\
\hline
\end{tabular}

${ }^{* *}$. Correlation is significant at the 0.01 level (2-tailed). 